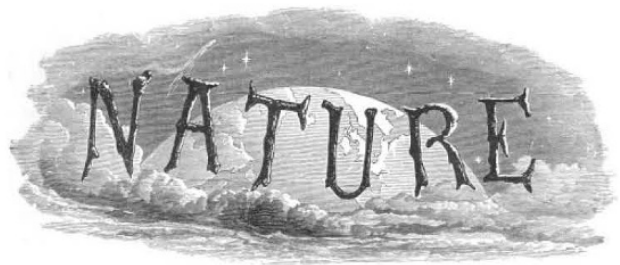

SATURDAY, FEBRUARY II, 1933

$$
\text { No. } 3302
$$$$
\text { Vol. } 131
$$

CONTENTS

Rubber Research

The Cost of a New World Order. By R. Brightman An Imperial City of China

Modern Genetical Studies. By w. B. T. :

Chemical Examination of Explosives. By Arthur Marshall

Short Reviews

Influence of the Pacific on the Circulation in the South-West Atlantic Ocean. By A. J. Clowes.

Helium Liquefaction Plant at the Clarendon Laboratory, Oxford. By Prof. F. A. Lindemann, F.R.S., and T.C. Keeley

Metrology by Light Waves at the National Physical Laboratory

Obituary :

Lieut.-Col. J. Stephenson, C.I.E., F.R.S. By Prof. J. H. Ashworth, F.R.S.

Dr. John Thomas. By W. J. P.

Mr. C. M. Stuart. By H. E. A.

News and Views

Letters to the Editor :

Origin of Curls and Twists in Wool Fibres.-Dr. J. E. Nichols

Further Mutations in the Amphipod Gammarus chevreuxi, Sexton.-Mrs. E. W. Sexton and Miss A. R. Clark

Distribution of Molybdenum-Dr. $\dot{W}$. A. Roach . . . . . .

Fluorescence of Lolium Seedlings in Ultra-Violet Light.-P. A. Linehan and Prof. S. P. Mercer

Teaching of Biology.-W. B. Yapp

Nuclear Moments of the Gallium Isotopes 69 and 71.-J. S. Campbell . .

Negative Polarisation in Fluorescence.-K. S. Krishnan and S. M. Mitra .

Synthesis of Chrysene and Certain Derivatives. -G. R. Ramage and Prof. R. Robinson, F.R.S.

Sex Hormones and Cancer-Producing Compounds.-Dr. J. W. Cook and Prof. E. C. Dodds, M.V.O.

Glutathione, Iodoacetic Acid and Glucose Metabolism.-Dr. J. H. Quaste

Rate of Burning of Colloidal Propellants.F. R. W. Hunt and G. H. Hinds

Research Items.

Astronomical Topics

Royal Society Mond Laboratory

International Congress of Scientific and Applied Photography, By S. O. R.

Electrolysis of Boron Hydrides

University and Educational Intelligence

Calendar of Nature Topics.

Societies and Academies

Forthcoming Events

Official Publications Received

Editorial and Publishing Offices:

MACMILLAN \& CO., LTD.

ST. MARTIN'S STREET, LONDON, W.C.2

Telephone Number: WHITEHALL 8831

Telegraphic Address : PHUSIS, LESQUARE, LONDON

\section{Rubber Research}

$\mathrm{F}$ REQUENT reference has been made in our columns to the importance of the relations between the State and industry in regard to research. Abundant evidence has been quoted to show that research on materials, methods of manufacture, and the properties of finished products not only benefits the industry concerned but also, directly and indirectly, the whole nation. Recognition of this common interest in research was shown by the grant in 1916 of a special fund to initiate and encourage co-operative research in Great Britain, and by the continuation of grants to the industrial research associations, which came into existence as a result of this policy, long after the end of the trial periods originally contemplated.

We are reminded of this community of interest by the announcement that the thirteen years' partnership between the rubber manufacturing industry and the State, through the Department of Scientific and Industrial Research, is to be dissolved unless assurance is immediately forthcoming that the finances of the Research Association of British Rubber Manufacturers can be established on a stable and adequate basis. The situation demands attention particularly because the fate of the Association now appears to rest with the House of Commons and possibly with the Government.

The Association, initiated in 1919 with fifteen members, has now grown to a membership of eighty-six firms, and is supported in addition by ninety-five subscribing firms and institutions interested in rubber but not qualified as actual manufacturers for full membership. A summary of the twelfth annual report was given in our columns (Nature, 129, 695, May 7, 1932), and from this it is evident that the Association has made itself increasingly useful, not only to its own members, but also to other trade and research associations and Government departments.

In recent years the financing of the Association has become increasingly difficult, partly owing to the industrial depression and partly owing to the constitution of the industry, consisting as it does of a large number of firms varying greatly in size. Some of the larger units, which have supported the Association both financially and scientifically from the beginning, are capable of carrying out research economically in their own factories and therefore take the view that they cannot continue to finance the Association in the common 
interest, except under some scheme by which all members of the industry contribute on a proportionate scale. To this end the Association has prepared a scheme by which it would be financed by the proceeds of a levy of one forty-fifth of a penny per $\mathrm{lb}$. on all raw rubber imported into Great Britain, thus spreading the burden uniformly over the units of the whole industry in proportion to their rubber consumption. This levy would secure an annual income to the Association of about $£ 15,000$. The scheme has been accepted by the majority of the firms in the industry and approved by the principal trade associations.

The financing of research or development by a levy on a basic material is not without precedent. The Cotton Industry Act of 1922 provides for the encouragement of cotton-growing in the British Empire by a levy on raw cotton; there is a cess on exported rubber for the upkeep of raw rubber research in Ceylon; and there is a levy on coal by which the Miners' Welfare Fund is financed in Great Britain. The idea of a levy for the support of a research association has also been considered favourably by more than one Parliamentary Committee. In its Final Report, the Balfour Committee on Industry and Trade stated :

"We have watched with interest and sympathy the steps taken by the rubber industry to secure the necessary funds for the operation of its research Association through a small levy on imported rubber. We hope that this scheme will receive legislative sanction, and that it may serve as an example to other industries to adopt measures, suited to their special conditions, for placing the finances of their research Associations on a permanently satisfactory basis."

Again, the Committee on New Industrial Development stated in its report:

"We do not consider that any general powers should be taken to enforce compulsory levies for the support of research Associations. Should an industry, however, succeed in working out a practicable scheme involving a compulsory levy for the support of a research Association, which it can show commands the support of a substantial majority of the industry, including the larger concerns, we consider that the Government should be ready to assist the Industry in obtaining the necessary Parliamentary powers."

The proposal for a levy in this case is embodied in the Rubber Industry Bill and has been four times before the House of Commons. When it was last debated, about two years ago, the opposition was based mainly on the objection of certain firms to compulsory support of an organisation which they considered to be of no value to them. In spite of this objection, the Bill obtained a second reading majority of 148 votes to 10 and passed through Standing Committee, but did not receive a third reading owing to lack of private members' time before the end of the session.

During the past year, a significant change in the situation has occurred. Many British industries, including the rubber industry, are now protected in the home market by a general tariff. Consequently, the technical efficiency of an industry cannot now be regarded as a purely domestic question for the industry itself. Whatever views might have been held a year ago on what the opposing firms called "the inalienable right of the British trader to carry on his trade without interference", it will be agreed that a protected industry should take a much less individualistic view of its obligations to the community, which voluntarily surrenders its right to carry on its buying without interference. In consideration of the benefits conferred by a tariff, the consumer has the right to expect the industry to give its best in return, and will not be greatly impressed by the plea of a minority which objects to a levy amounting on the average to about 1/1800th part of the selling value of its products for the purpose of improving the scientific and technical efficiency of the industry. In these circumstances, there is little doubt what the verdict of the House of Commons would be if the Bill were to obtain another debate and division.

Unfortunately, this seems unlikely to occur; for the prospects of the passage of a private member's Bill against even the slightest opposition are so small that arrangements have already been made for disbanding the staff of the Research Association when its financial resources are exhausted at the end of this month. If the organisation is to be kept together, action must be taken quickly and the only course now left open seems to be for the Government to declare itself in favour of the principle of the Bill and give it facilities for passing through its further stages. Indeed, considering the dependence of all the industrial research associations on State assistance, it is surprising that the Government, once it adopted tariffs, failed to earmark a part of the revenue thus obtained for the more earnest prosecution of research in every branch of industry. 